29 電子回路による商用周波点灯方式の検討

清水 恵一（東芝ライテック株式会社）

\title{
1.はじめに
}

放電ランプを電子回路を用いて点灯する方式には、インバー夕を用いて高周波点灯する方式や、商用周波の限 流要素と電子回路を組合わせたハイブリッド方式がある。今回これらの方式とは別に、電子回路を用いて直接商 用周波点灯を行う方式について検討したので報告する。

\section{2. 回路方式}

図 1 は交流電源に誘導性の限流要素を介して放電灯 を接続した点灯回路の基本である。ここで限流要素の 偟きを考えると、それ自身は電力を消費しないで瞬時 電力を蓄え、放出する動作をくり返す無効電力発生装 置となっていることがわかる。この瞬時電力を蓄える 作用を行っているのが商用周波点灯では安定器の磁気 回路である。周知の通り磁気回路は重量・体積ともに 大きい。これに対してコンデンサ, 特に電解コンデン サは蓄えるエネルギー密度が磁気回路に比べ約 400 倍も大きいので、これを瞵時電力の蓄積素子として用 いることで安定器を大巾に小形化することが可能とな る。コンデンサの充放電を制御するためにスイッチン グ回路を用いて構成した電子化限流回路を図 2 に示す。 この回路は印加される電圧と電流の極性により動作 状態を 4 期間に分けることができる。（図 3．4）(1) と(3)の期間, 回路は昇圧形チョッパとして動作しコン テンサを充電する。(2)と(4)の期間はコンデサを電源 とし降圧形のチョッパとして動作しエネルギーを放出 する。動作周期に従って適切にスイッチ素子を切換え かつスイッチングの時比率を制御することによってラ ンプ電流の波形を操作することが可能である。ランプ 電流波形を矩形波になるように制御することで、商用 周波点灯であっても再点弧ロスを無くして高効率の点 灯装置を実現することができる。また、再点弧の問題 を解決し瞕時電流制御を行えば電源電圧に対し進相で も遅相でも動作し得るものである。

3.おわりに

高周波点灯に依らないで、商用周波の限流要素をそ のまま電子回路に置き換える方法で新しい点灯回路を 実現することができた。小形軽量化とともに、ランプ 電流波形改善により商用周波点灯でありながら総合効 率改善にも可能性があることがわかった。

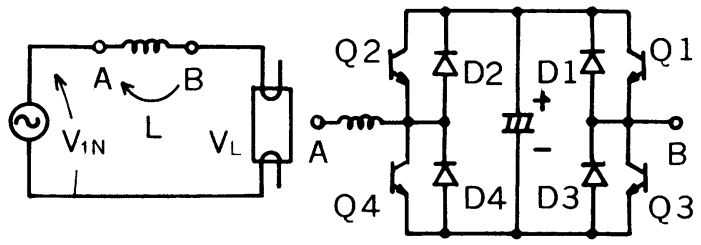

図 1. 基本点灯回路 図 2 . 電子化限流回路
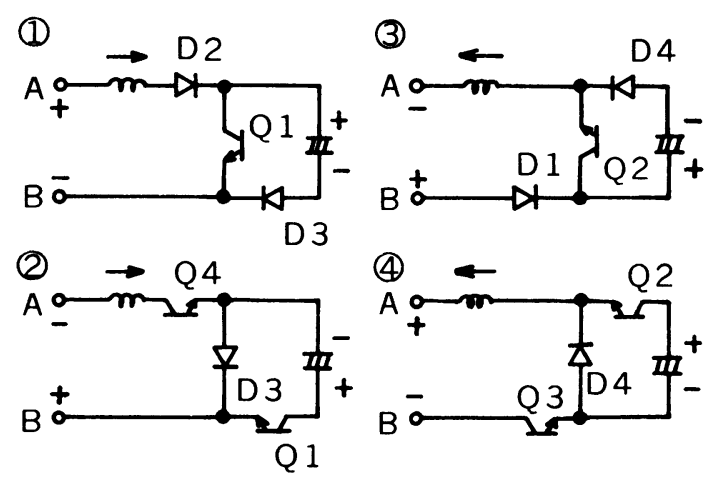

図 3. 回路動作説明図

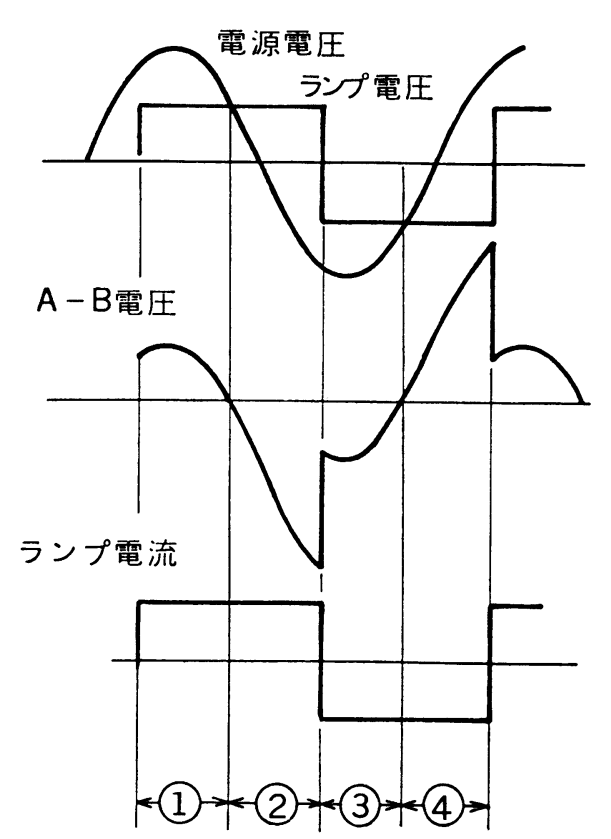

図 4. 動作波形図 